\title{
CORRIGENDUM
}

Genes \& Development 33: 258-275 (2019)

\section{Corrigendum: 'Building a perfect body': control of vertebrate organogenesis by PBX-dependent regulatory networks}

Licia Selleri, Vincenzo Zappavigna, and Elisabetta Ferretti

In the above-mentioned article, the funding source NNF17CC0027852 to Elisabetta Ferretti was missing from Acknowledgments and has been added as follows: "This work was supported by The Novo Nordisk Foundation Center for Stem Cell Biology (NNF17CC0027852 to E.F.)."

doi: $10.1101 / \operatorname{gad} .326298 .119$ 


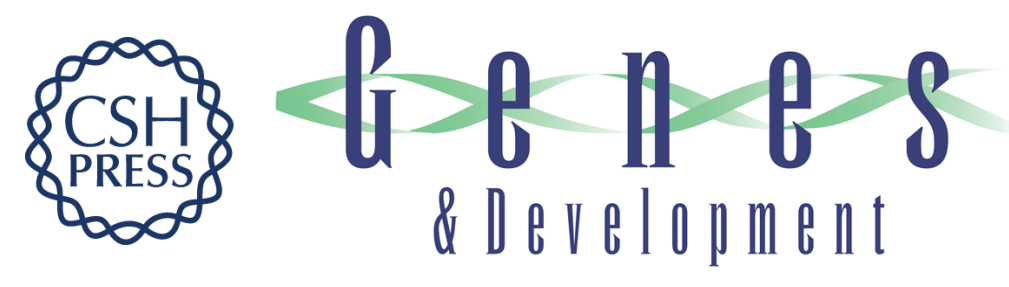

\section{Corrigendum: 'Building a perfect body': control of vertebrate organogenesis by PBX-dependent regulatory networks}

Licia Selleri, Vincenzo Zappavigna and Elisabetta Ferretti

Genes Dev. 2019, 33:

Access the most recent version at doi:10.1101/gad.326298.119

Related Content Building a perfect bod
regulatory networks

Licia Selleri, Vincenzo Zappavigna and Elisabetta Ferretti

Genes Dev. March , 2019 33: 258-275

\section{License}

Email Alerting

Service
Receive free email alerts when new articles cite this article - sign up in the box at the top right corner of the article or click here.

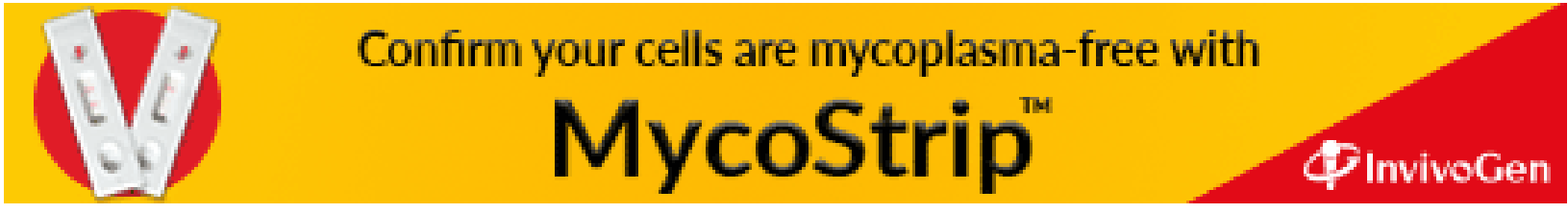

